\title{
The Endopolygalacturonase Gene Bcpg1 Is Required for Full Virulence of Botrytis cinerea
}

\author{
Arjen ten Have, ${ }^{1}$ Wietse Mulder, ${ }^{2}$ Jaap Visser, ${ }^{2}$ and Jan A. L. van Kan ${ }^{1}$ \\ ${ }^{1}$ Laboratory of Phytopathology, Graduate School of Experimental Plant Sciences, Wageningen Agricultural \\ University, Binnenhaven 9, 6709 PD Wageningen, The Netherlands; ${ }^{2}$ Section of Molecular Genetics \\ of Industrial Microorganisms, Wageningen Agricultural University, Dreijenlaan 2, 6703 HA Wageningen, \\ The Netherlands \\ Accepted 30 June 1998.
}

\begin{abstract}
Botrytis cinerea, a fungus that causes diseases in over 200 plant species, secretes a number of endopolygalacturonases that have been suggested to be involved in pathogenesis. However, so far the corresponding genes have not been isolated from this fungus. We cloned Bcpg1, encoding endopolygalacturonase, with the pgaII gene from Aspergillus niger as a heterologous probe. The Bcpg1 gene is expressed to similar levels in liquid cultures of $B$. cinerea containing either $1 \%$ polygalacturonic acid or $1 \%$ sucrose, and is expressed during infection of tomato leaves. The Bcpg1 gene was eliminated by partial gene replacement, and the resulting mutants were tested for virulence on tomato leaves and fruits, as well as on apple fruits. Although the mutants were still pathogenic and displayed similar primary infections when compared with control strains, a significant decrease in secondary infection, i.e., growth of the lesion beyond the inoculation spot, was observed on all three host tissues. These results indicate that the Bcpg1 gene is required for full virulence.
\end{abstract}

Additional keywords: gray mold, pathogenicity, pectin.

The plant pathogen Botrytis cinerea Pers.: Fr. (teleomorph: Botryotinia fuckeliana (de Bary) Whetzel), the causal agent of gray mold, is renowned for its broad host range. Over 200 species can be infected (Jarvis 1977), resulting in considerable economic losses. The fungus often invades senescent or damaged plant tissue. Since the fungus is able to cause disease in plants at temperatures down to $2^{\circ} \mathrm{C}$, it causes many problems in post-harvest chains. To establish successful infection on healthy, undamaged tissue, supplementation with nutrients is necessary (Rijkenberg et al. 1980). Therefore, B. cinerea is regarded as a weak pathogen.

An important function for a cutinase was suggested by studies on the penetration of bean and tomato cuticles (Rijken-

Corresponding author: Jan A. L. van Kan, Laboratory of Phytopathology, Wageningen Agricultural University, P.O. Box 8025, 6700 EE Wageningen, The Netherlands; Telephone: +31 317-483 126, Fax: +31 317-483 412; E-mail: Jan.vankan@ medew.fyto.wau.nl

Nucleotide and/or amino acid sequence data are to be found in the GenBank/EMBL/DNA Data Bank of Japan under accession number U68715. berg et al. 1980). Reduction of lesion formation in gerbera flowers, as a result of treatment with antibodies raised against cutinase A, supported this hypothesis (Salinas 1992). However, gene disruption studies demonstrated that cutinase $\mathrm{A}$ is not essential for the infection of both tomato fruits and gerbera flowers (van Kan et al. 1997), suggesting that penetration of the cuticle occurs either by mechanical breaching or by other enzymes (Clark and Lorbeer 1976; van Kan et al. 1997).

Many reports describe the secretion of cell wall degrading enzymes (CWDEs) by $B$. cinerea during early stages of infection. This is accompanied by a swelling of the epidermal cell wall, suggesting that the CWDEs are actively involved in penetration (Elad and Evensen 1995; Mansfield and Richardson 1981). However, it cannot be excluded that CWDEs are not required during penetration, but are rather involved in the degradation of the cell wall during subsequent host tissue invasion.

Among the $B$. cinerea CWDEs described, an endopolygalacturonase (endoPG; E.C. 3.2.1.15) with a basic pI is one of the first enzymes that is secreted (Johnston and Williamson 1992a, 1992b; Leone and van den Heuvel 1987; van der Cruyssen et al. 1994). Activity of this enzyme, denoted as PG-A (van der Cruyssen et al. 1994), PG2 (Leone and van den Heuvel 1987) or PG-II (Johnston and Williamson 1992a, 1992b), is found when the fungus is grown on polygalacturonic acid (PGA) as well as on sucrose. In planta, PG-A is predominantly detected in the outer zone of the infected area, whereas other endoPGs are only detected in the central zone of the infected area (Kamoen and van der Cruyssen 1996). Although much biochemical research has been performed, there is no clear understanding of the possible functions of endoPGs in the pathogenesis of $B$. cinerea. Molecular genetic studies in several other plantpathogenic fungi have not given support for a role in pathogenesis for these enzymes (reviewed by Annis and Goodwin 1997). However, it was recently reported that the elimination of an endoPG in the saprophytic fungus Aspergillus flavus resulted in a mutant with reduced virulence on cotton bolls (Shieh et al. 1997). Here we describe the isolation, characterization, and elimination of Bcpg1, a member of an endoPG gene family from $B$. cinerea, and provide evidence that this gene plays a functional role during pathogenesis on three different host plant tissues. 


\section{RESULTS}

Bcpg1 is a member of a gene family encoding endoPGs.

The $B c p g 1$ gene was isolated from a genomic $\lambda$-EMBL3 library (Kusters-van Someren et al. 1992) with the pgaII gene from Aspergillus niger as a heterologous probe. Twenty-two strongly hybridizing and 50 weakly hybridizing plaques were identified in a primary screening of $1.5 \times 10^{5}$ plaques $(30$ genome equivalents). Two of the 22 strongly hybridizing plaques were identified as false positives in a secondary screening. DNA from purified recombinant phage 25 , one of the intensely hybridizing phages, was subjected to Southern analysis. Two overlapping hybridizing fragments were isolated from this phage, cloned, and used for sequence analysis. Figure 1A shows a restriction map of $B$. cinerea genomic DNA encompassing the region of DNA that hybridized to the heterologous probe. DNA sequence analysis of this region revealed an open reading frame of $1,149 \mathrm{bp}$. Putative core promoter elements, such as TATA and CAAT motifs, are present (Fig. 2), but the sequence lacks a typical polyadenylation signal. There were no obvious introns on the basis of homology to polygalacturonases and the percentage of GC in third base of the codons (Ficket 1982). The predicted translation product (Fig. 2) contains a putative cleavage site for a signal peptide

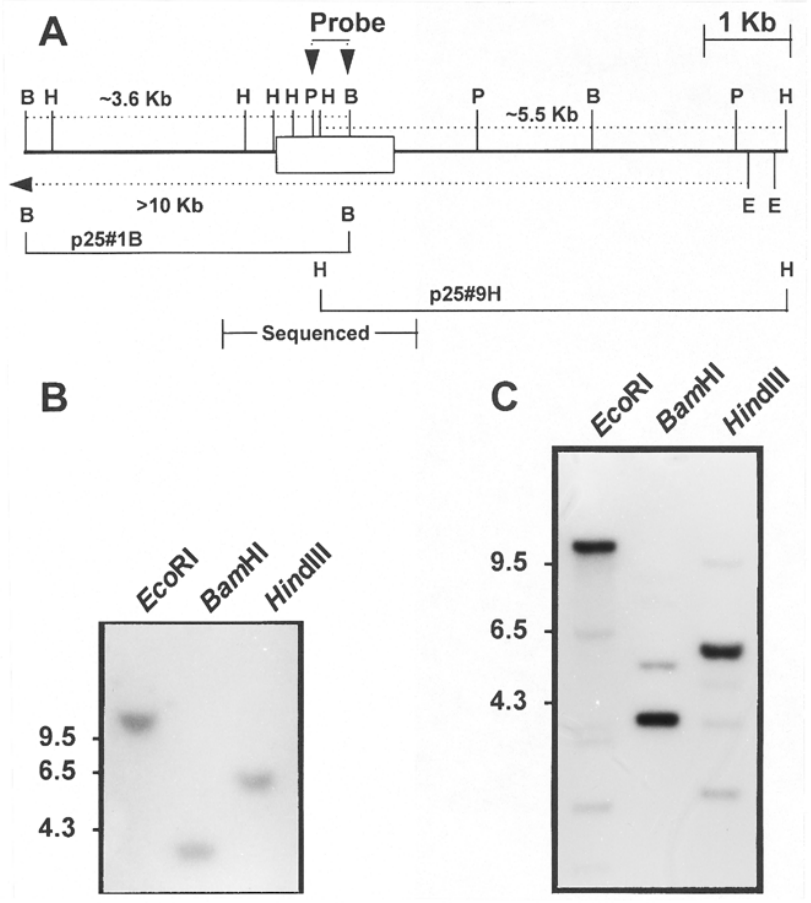

Fig. 1. Analysis of Bcpg 1 locus. A, Restriction map of cloned genomic DNA encompassing the Bcpg 1 gene. Phage 25 contained two overlapping restriction fragments, $25 \# 1 \mathrm{~B}$ and $25 \# 9 \mathrm{H}$, which hybridized to the 700-bp SalI pgaII probe from Aspergillus niger. Sequenced region identified an open reading frame, indicated by open box. Probe indicates the part of the gene used for Southern analysis; dashed lines indicate hybridizing fragments. B: BamHI, E: EcoRI, H: HindIII, P: PstI (B). B, Southern blot analysis of genomic DNA. Each lane contains $2 \mu \mathrm{g}$ of genomic DNA from strain SAS56 digested with restriction enzymes as indicated. Blot was hybridized with probe indicated in $\mathbf{A}$, and washed at high stringency conditions. C, Low stringency hybridization of blot shown in B. Molecular sizes determined by comparison with comigrated HindIII digested $\lambda$ DNA, indicated on left $(\mathrm{kb})$. between $\mathrm{Ala}^{20}$ and $\mathrm{Ala}^{21}$ (Nielsen et al. 1997). By analogy to PGII from A. niger, $\mathrm{Arg}^{42}$ might serve as a monobasic cleavage site (Visser et al. 1995). This would result in a mature protein, designated BcPG1, consisting of 341 amino acids with a predicted molecular mass of $33.7 \mathrm{kDa}$ and a calculated pI of 8.07. The protein contains an $\mathrm{N}$-glycosylation signal at position 316 and it contains all nine amino acids that are conserved among all known exopolygalacturonases (exoPGs) and endoPGs (Benen et al. 1996). BcPG1 shows 53\% amino acid identity to PGII from A. niger and $84 \%$ to PG1 from Sclerotinia sclerotiorum, a closely related plant-pathogenic fungus.

A DNA blot was hybridized with a part of the Bcpg 1 coding sequence, indicated in Figure 1A. A single band was observed under stringent conditions for all three restriction enzyme digests, indicating that Bcpg1 is a single-copy gene (Fig. 1B). At low stringency, up to five additional bands were detected. (Fig. 1C).

\section{Bcpg1 is expressed during infection of tomato leaves.}

Following inoculation with a conidial suspension of strain B05.10, a haploid derivative of strain SAS56, the leaves were incubated under conditions that result either in leaf spot $\left(20^{\circ} \mathrm{C}, 16\right.$-h light period) or soft $\operatorname{rot}\left(4^{\circ} \mathrm{C}\right.$, in the dark). Watersoaked lesions appeared $16 \mathrm{~h}$ post inoculation (HPI), when leaves were incubated at $20^{\circ} \mathrm{C}$. All lesions became brown and necrotic within $22 \mathrm{HPI}$. Of these initially formed lesions, in general 10 to $20 \%$ showed aggressive growth, i.e., rapid expansion beyond the inoculation spot. The remaining 80 to $90 \%$ of the initially formed lesions did not expand at all. The aggressive lesions fully colonized the leaf at $144 \mathrm{HPI}$. At $4^{\circ} \mathrm{C}$, the lesions appeared at $18 \mathrm{HPI}$, and did not become necrotic. All lesions expanded, resulting in full leaf maceration at $192 \mathrm{HPI}$.

Samples of infected plant material were taken for RNA extraction at six timepoints after inoculation, while RNA isolated from overnight-grown liquid cultures of $B$. cinerea served as a control. Figure 3 shows the expression of $B c p g 1$ and the constitutively expressed actin gene (BcactA), which is taken as a measure for the fungal biomass (Benito et al. 1998). Bcpg 1 transcript levels are similar when B05.10 is grown on either sucrose or PGA. In planta, Bcpg1 transcript can be detected at $16 \mathrm{HPI}$ at $20^{\circ} \mathrm{C}$ (Fig. 3A), when typically 1 to $5 \%$ of the total RNA is of fungal origin (Benito et al. 1998). The Bcpg1 transcript level increases during the course of the infection process in a way similar to that of the BcactA transcript. The small decrease in the hybridization level of both transcripts, at $48 \mathrm{HPI}$ in the $20^{\circ} \mathrm{C}$ time course, is probably the result of a sample that was less well infected, when compared with the other samples. At $4^{\circ} \mathrm{C}$, the Bcpg 1 transcript is first detected by hybridization at 32 HPI. The Bcpg 1 transcript level is low during early infection and increases at later stages of the infection process, when compared with the BcactA transcript level (Fig. 3B).

\section{Construction and characterization of Bcpg1 mutants.}

Bcpg1 elimination mutants were made by transformationmediated gene replacement in haploid strain B05.10. A part of the coding sequence of Bcpg1 was exchanged by a cassette containing the $h p h$ gene, which confers resistance to hygromycin, as depicted in Figure 4A. Fifty independent hygromycin resistant colonies were isolated from five separate transformation experiments. The transformants were further 
purified by two subsequent transfers to high selection plates and by two subsequent isolations of single germinating conidia, in order to obtain homokaryotic transformants. Polymerase chain reaction (PCR) detected the replacement of the locus in five transformants. Correct replacement was confirmed in transformants $\Delta 1$ and $\Delta 39$ by Southern analysis (Fig. $4 \mathrm{C}$ ). No additional ectopic integrations were detected by hybridization and no Bcpg1 mRNA was detectable on blots in mutants $\Delta 1$ and $\Delta 39$ when grown on PGA or sucrose (not shown). The mutants did not show significant polygalacturonase activity when grown on sucrose for $6 \mathrm{~h}$, whereas a clear activity was found for the wild type. On agarose plates containing sucrose, the mutants showed no significant difference in radial growth compared with wild-type strain B05.10. However, when grown on PGA as sole carbon source, the mutants showed reduced growth.

\section{Bcpg1 mutants are less virulent on tomato leaves.}

The effect of Bcpg 1 elimination on primary infection, i.e., the ability to penetrate the leaf epidermis, as well as on secondary infection, i.e., the subsequent invasion of surrounding tissue, was determined in droplet inoculation experiments on tomato leaves. If BcPG1 is involved in the penetration of the epidermis, the mutants might be expected to give either a lower frequency of primary infection or a delay in the process of primary infection, while if BcPG1 is involved in the subsequent invasion of surrounding tissue it might be expected that the mutants would exhibit a reduced outgrowth of primary lesions. $B$. cinerea causes disease at both moderate $\left(20^{\circ} \mathrm{C}\right)$ and low $\left(4^{\circ} \mathrm{C}\right)$ temperatures. Therefore, the efficacy of primary and secondary infection was tested at both temperatures.

There was no reduction or delay in lesion initiation by the mutants at either 20 or $4^{\circ} \mathrm{C}$, compared with the recipient strain. However, the mutants displayed a smaller number of
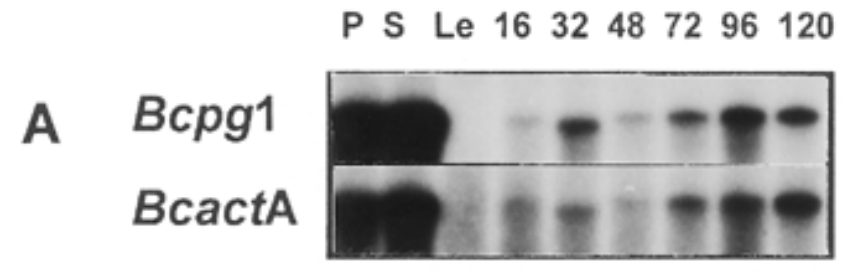

$\begin{array}{llllll}16 & 32 & 48 & 72 & 96 & 120\end{array}$

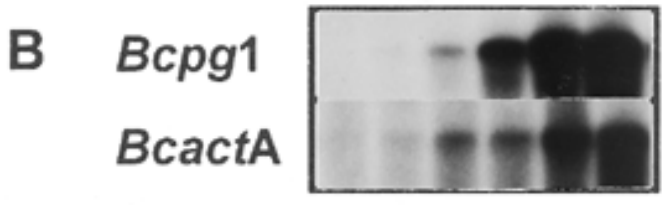

Fig. 3. Northern (RNA) blot analysis of time course infection of tomato leaves. A, $20^{\circ} \mathrm{C}$ incubation: P: $1 \%$ on polygalacturonic acid (PGA), S: $1 \%$ sucrose (controls from liquid cultures), Le: uninoculated tomato leaf, and time course infection $(16,32,48,72,96,120 \mathrm{~h}$ post inoculation $[\mathrm{HPI}]) . \mathbf{B}, 4^{\circ} \mathrm{C}$ incubation $(16,32,48,72,96,120 \mathrm{HPI})$. Blot was consecutively hybridized with gene-specific Bcpg1 and BcactA fragments, the latter encoding actin. Each lane contains $20 \mu \mathrm{g}$ of total RNA. Loading was checked by staining blot with ethidium bromide (not shown).

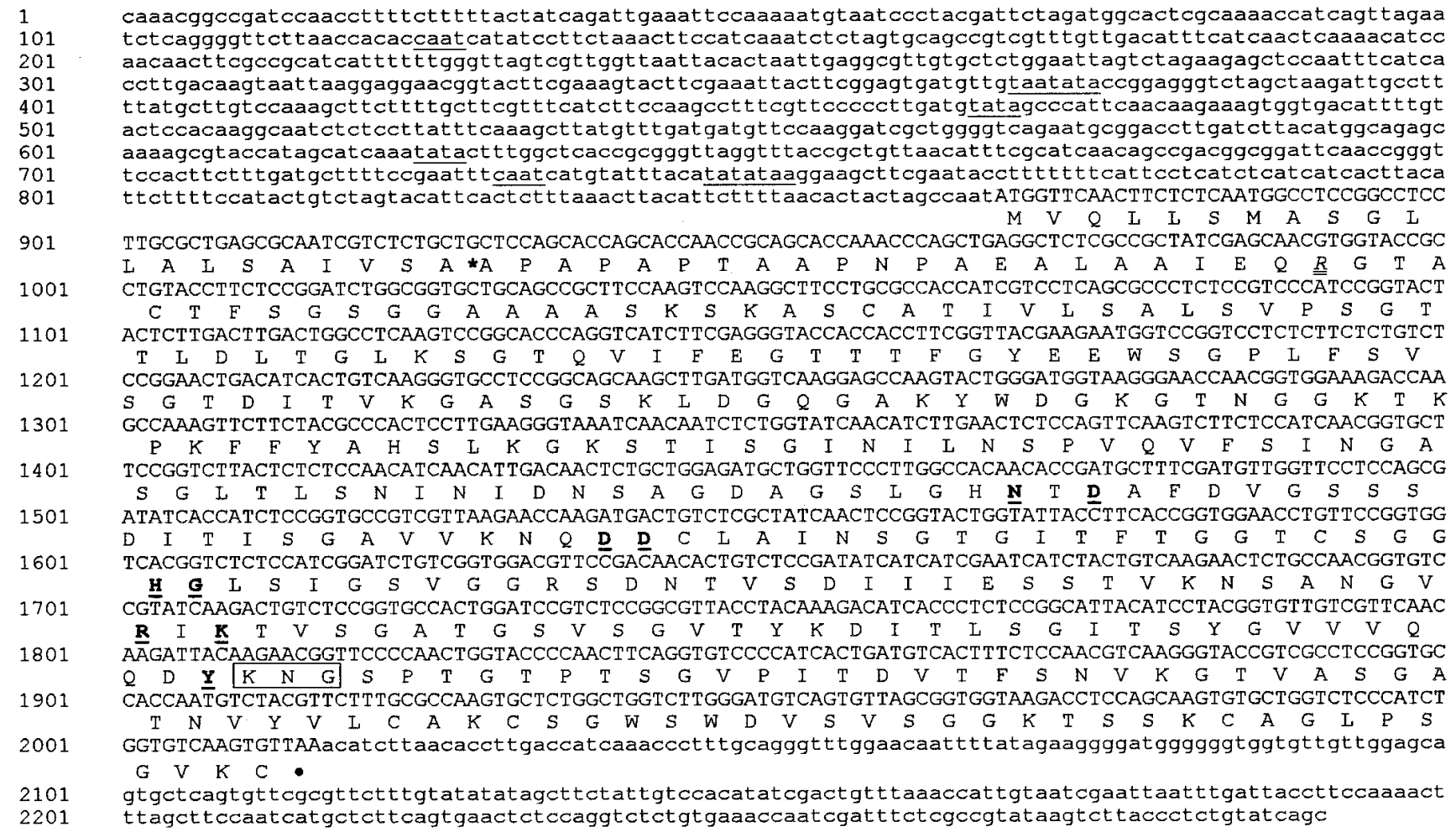

Fig. 2. Nucleotide sequence of the Bcpg1 gene from Botrytis cinerea. Coding sequence is in uppercase; deduced amino acid sequence is indicated underneath. Possible core promoter motifs are underlined. Amino acid residues that are strictly conserved among polygalacturonases are underlined and indicated in bold. A cleavage site for a proposed signal sequence is indicated by an asterisk (*); putative monobasic protease cleavage site is double underlined. Potential N-glycosylation site is boxed. 
aggressive lesions at $20^{\circ} \mathrm{C}$, compared with recipient strain B05.10 (Table 1). Furthermore, the mutants show less extensive development of lesions at $4^{\circ} \mathrm{C}$ compared with the recipient strain B05.10 (Fig. 5). Measurement of lesion size at 72 and 96 HPI indicated that the reduction in lesion growth rate over this period was significant in all experiments $(P<0.05,<$ 0.01 , or $<0.001$, depending on the experiment; see Table 2). Similar results were obtained when mutant $\Delta 39$ was compared with a transformant with a single-copy integration outside the Bcpg1 locus, T132 ( $P<0.001$; see Table 2).

\section{Bcpg1 mutants are less virulent on apple and tomato fruits.}

The mutants showed less aggressive growth on both apple and tomato fruits. Droplets of 5- $\mu$ l conidial suspension were applied to wounded apple or tomato fruits. Apples developed

A

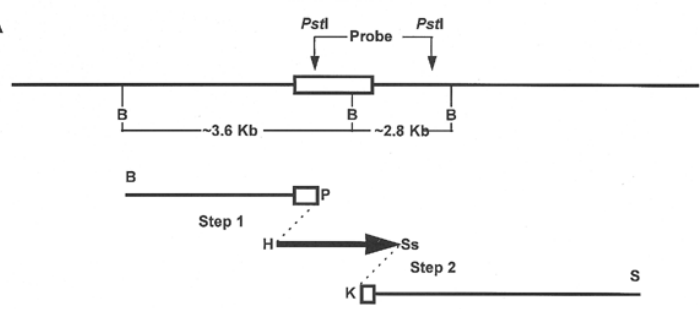

B

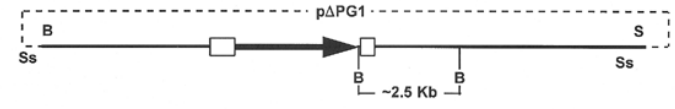

C

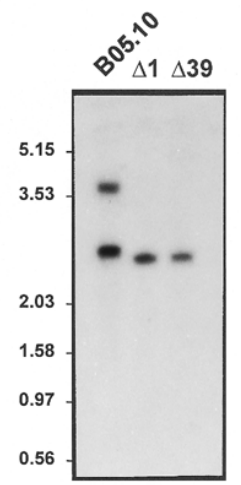

Fig. 4. Bcpg1 gene replacement. A, Schematic representation of subcloning of replacement construct. All cloning steps were performed by blunt-end ligation. The $h p h$ cassette, indicated by arrow, was first ligated to the $5^{\prime}$ terminus of the Bcpg 1 gene (Step 1). Subsequently, the $3^{\prime}$ terminus was cloned after the hph cassette (Step 2). B, Replacement construct $\mathrm{p} \Delta \mathrm{PG} 1$ in which approximately $700 \mathrm{bp}$ of the coding sequence are exchanged with the $h p h$ cassette. The resulting construct was digested with SstI in order to obtain linear replacement DNA without vector sequences. C, Southern blot analysis of transformants $\Delta 1$ and $\Delta 39$ compared with recipient strain B05.10. Genomic DNA $(1 \mu \mathrm{g})$ was isolated from recipient strain $\mathrm{B} 05.10$ and transformants and digested with BamHI. Probe indicated in A hybridizes to 3.6- and a 2.8-kb fragments of the recipient strain (A) and to a $2.5-\mathrm{kb}$ fragment of the transformants (B). Molecular sizes were determined by comparison with comigrated HindIII/EcoRI digested $\lambda$ DNA, indicated on left (kb). Open box in A and $\mathbf{B}$ indicates Bcpg 1 coding sequence; solid lines indicate flanking sequences. B, Dashed line indicates vector sequences. B: BamHI, P: PstI, H: HindIII, S: SalI, K: KpnI, Ss: SstI. brown, rotten lesions around the inoculation sites at $48 \mathrm{HPI}$, when incubated at $20^{\circ} \mathrm{C}$. The growth of lesions formed by the Bcpg1 elimination mutant between 48 and 112 HPI was significantly reduced $(P<0.001)$ compared with the control, T132 (see Table 3). Similar results were obtained in a second experiment.

Inoculated tomato fruits incubated at $4^{\circ} \mathrm{C}$ developed lesions of soft rot at 112 HPI. In a first experiment the growth rate of the lesions formed by the Bcpg 1 elimination mutant between 112 and 206 HPI was significantly reduced $(P<0.001)$, when compared with the control, T132 (see Table 3). In two subsequent experiments, lesion growth rate was also significantly reduced $(P<0.01)$. In a fourth experiment, growth of the mutant appeared less aggressive but the reduction was statistically not significant.

\section{DISCUSSION}

\section{Bcpg1 encodes an endoPG.}

The Bcpg 1 gene has all the features of a secreted endoPG, including a preprosequence and all amino acids strictly conserved among exoPGs and endoPGs (Benen et al. 1996). The predicted amino acid sequence displays high identity with PGII from A. niger and PG1 from S. sclerotiorum. For $B$. cinerea, up to 13 endoPG isozymes have been described, of which only 2 have a basic pI. A constitutive endoPG, PGII, was shown to have a pI of 8.8 and a molecular mass of 36 $\mathrm{kDa}$ (Johnston and Williamson 1992a, 1992b), while in a separate study an isozyme denoted as PG-A was shown to have a pI of approximately 9 (van der Cruyssen et al. 1994). These reports are in reasonable agreement with the data calculated for the mature BcPG1 $(\mathrm{pI}=8.07$ and molecular mass $=33.7 \mathrm{kDa}$ ). PG-A was the only isozyme that seemed to be produced constitutively, albeit in a growth-dependent manner (Leone and van den Heuvel 1987; van der Cruyssen et al. 1994). This is in agreement with our observation that Bcpg1 is constitutively expressed in planta and in liquid medium containing PGA, sucrose (Fig. 3), or both (data not shown). We conclude that Bcpg1 is likely to encode the PGA isozyme. Since Southern analysis indicates the likely presence of more endoPG genes (Fig. 1C), we are currently in the process of cloning and characterizing additional members of the endoPG gene family.

Table 1. Number of expanding lesions formed upon infection by BcPG1 deficient strains $\Delta 1$ or $\Delta 39$ and by wild type-strain $\mathrm{B} 05.10$ at $20^{\circ} \mathrm{C}^{\mathrm{a}}$

\begin{tabular}{lcccc}
\hline & \multicolumn{4}{c}{ Expanding lesions (no.) } \\
\cline { 2 - 5 } Experiment & $\mathbf{n}$ & $\Delta \mathbf{1}$ & $\Delta \mathbf{3 9}$ & $\mathbf{B 0 5 . 1 0}$ \\
\hline 1 & 40 & 0 & - & 10 \\
2 & 20 & 1 & - & 6 \\
3 & 20 & 1 & - & 2 \\
4 & 60 & - & 0 & 6 \\
5 & 60 & 9 & - & 24 \\
6 & 60 & - & 15 & 30 \\
\hline
\end{tabular}

${ }^{a}$ From each plant one detached leaf was taken, four leaflets of which were inoculated with, from each strain indicated, five $1-\mu \mathrm{l}$ droplets containing approx. $10^{3}$ conidia. Leaves were incubated at $20^{\circ} \mathrm{C}$ with a 16-h photoperiod; lesions that expanded beyond inoculation spot before $120 \mathrm{~h}$ post inoculation were scored as expanding lesions. $\mathrm{n}=$ total number of inoculation droplets per strain; $-=$ not done. Conidia germination rate was always between 70 and $80 \%$. 
The $B$. cinerea PG1 has a functional role in pathogenesis.

The endoPG BcPG1 is involved in pathogenesis. Although the initial infection frequency was not notably influenced by the replacement of the $B c p g 1$ gene, a significant reduction in lesion growth rate on tomato leaves and fruits as well as on apple fruits was observed (Tables 1-3). Radial growth on sucrose as a carbon source was not influenced by the elimination of the Bcpg 1 gene, although mutants showed reduced growth on medium containing PGA as sole carbon source.

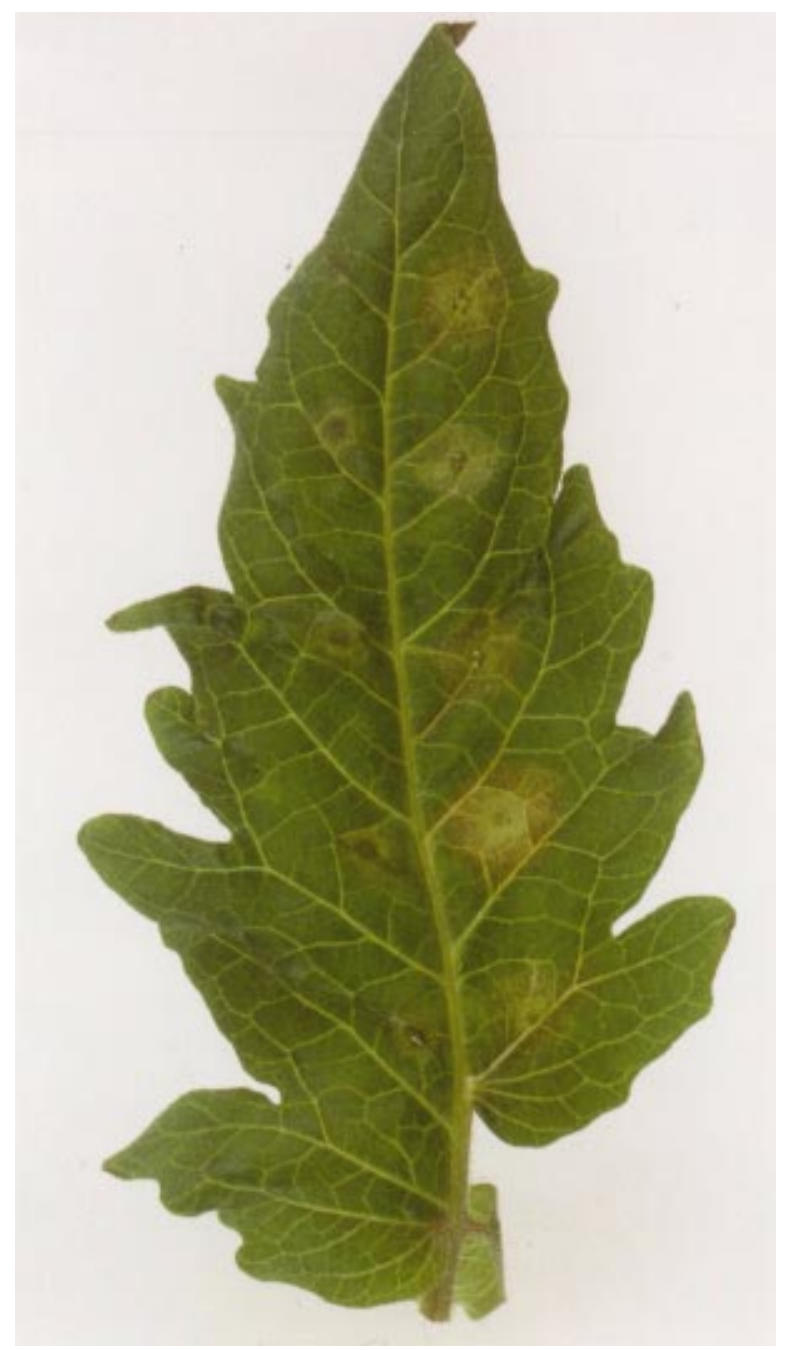

Fig. 5. Virulence assay of mutant $\Delta 39$ on tomato leaflet at $4^{\circ} \mathrm{C}$. Leaflet was inoculated with conidia of (left part) $\Delta 39$ and (right part) recipient strain B05.10. Photo taken at $144 \mathrm{~h}$ post inoculation.
No difference was observed in the initial steps of infection, i.e., during the first 16 to $32 \mathrm{~h}$ of infection, even though Bcpg 1 is expressed in the wild type at this stage of infection, at least at $4^{\circ} \mathrm{C}$ (Fig. 3). Therefore, it is unlikely that BcPG1 has an important function in penetration, as suggested by a number of authors (Elad and Evensen 1995; Mansfield and Richardson 1981).

Targeted replacement mutants have been constructed in a variety of presumed pathogenicity genes of several fungi, and have confirmed their involvement in pathogenesis (e.g., Perpetua et al. 1996; Shi and Leung 1995; Wassmann and VanEtten 1996). However, except for one case, the elimination of CWDEs in plant-pathogenic fungi has thus far not indicated that these enzymes play any significant role in pathogenesis. This was studied most extensively in Cochliobolus carbonum by Walton and co-workers. Eliminations of a cellulase (Sposato et al. 1995), an exo- $\beta$-1-3-glucanase (Schaeffer et al. 1994), MLG1 encoding two $\beta$-1,3-1,4-glucanases (Görlach et al. 1998), an endoPG (Scott-Craig et al. 1990), and an exoPG (Scott-Craig et al. 1998) did not result in reduced virulence on maize. Even the elimination in one strain of both an endoPG and an exoPG (Scott-Craig et al. 1998), as well as of three different $\beta$-1,4-xylanases (Apel-Birkhold and Walton 1996), had no effect on virulence.

Also in other plant-pathogenic fungi, genes encoding CWDEs have been eliminated. A pectin lyase deficient mutant of Glomerella cingulata (Bowen et al. 1995) and an endoPG (enpg-1) mutant of Cryphonectria parasitica (Gao et al. 1996) did not display a phenotype different from the corresponding wild type. The $\beta-1,4$-xylanase mutant of $C$. carbonum showed wild-type growth on the specific substrate whereas substantial residual enzyme activity was found in

Table 3. Radial lesion growth on tomato $\left(4^{\circ} \mathrm{C}\right)$ and apple fruit $\left(20^{\circ} \mathrm{C}\right)$ after infection by BcPG1-deficient strain $\Delta 39$ and a control strain $(\mathrm{T} 132)^{\mathrm{a}}$

\begin{tabular}{lccccc}
\hline & & \multicolumn{2}{c}{ Radial growth \pm SD $(\mathbf{m m})$} & & $\begin{array}{c}\text { Growth } \\
\text { Host }\end{array}$ \\
& $\mathbf{n}$ & $\mathbf{T 1 3 2}$ & $\Delta \mathbf{3 9}$ & $\boldsymbol{t}$ test & reduction \\
\hline Apple & 38 & $28.0 \pm 3.97$ & $21.8 \pm 5.81$ & $3.9 \mathrm{E}-5$ & $22 \%$ \\
Tomato & 38 & $17.2 \pm 4.23$ & $13.3 \pm 3.35$ & $1.34 \mathrm{E}-6$ & $23 \%$ \\
\hline
\end{tabular}

${ }^{a}$ Fruits were inoculated with, from each strain indicated, $5-\mu l$ droplets containing $5 \times 10^{3}$ conidia. Upon inoculation, tomato fruits were incubated at $4{ }^{\circ} \mathrm{C}$ in the dark, apple fruits at $20^{\circ} \mathrm{C}$ with a $16-\mathrm{h}$ photoperiod. Radial growth was determined after the lesion had extended beyond inoculation spot over a 56-h timespan for apple fruits (48 to $104 \mathrm{~h}$ post inoculation [HPI]) and over a 94-h timespan for tomato fruits (112 to $206 \mathrm{HPI})$. $\mathrm{n}=$ total number of inoculation droplets per strain. $\mathrm{SD}=$ standard deviation. Statistical analysis was performed with a $t$ test. Conidia germination rate was always between 70 and $80 \%$.

Table 2. Radial growth of lesions on tomato leaves after infection by BcPG1-deficient strains $\Delta 1$ or $\Delta 39$ and control strains B05.10 or T132 ( $\left.{ }^{\circ} \mathrm{C}\right)^{\mathrm{a}}$

\begin{tabular}{|c|c|c|c|c|c|c|c|}
\hline \multirow[b]{2}{*}{ Experiment } & \multirow[b]{2}{*}{$\mathbf{n}$} & \multirow[b]{2}{*}{ Control B05.10 } & \multicolumn{3}{|c|}{ Radial growth \pm SD $(\mathbf{m m})$} & \multirow[b]{2}{*}{$t$ test } & \multirow[b]{2}{*}{ Growth reduction } \\
\hline & & & Control T132 & Mutant $\Delta 39$ & Mutant $\Delta \mathbf{1}$ & & \\
\hline 1 & 20 & $4.4 \pm 1.1$ & - & $3.4 \pm 0.62$ & - & 0.003 & $22 \%$ \\
\hline 2 & 20 & $3.6 \pm 1.0$ & - & - & $3.1 \pm 0.62$ & 0.048 & $14 \%$ \\
\hline 3 & 30 & $5.0 \pm 1.1$ & - & $2.3 \pm 0.54$ & - & $1.6 \mathrm{E}-10$ & $54 \%$ \\
\hline 4 & 30 & - & $3.6 \pm 0.31$ & $2.3 \pm 0.30$ & - & 0.0005 & $37 \%$ \\
\hline
\end{tabular}

a From each plant one detached leaf was taken, four leaflets of which were inoculated with, from each strain indicated, five 1- $\mu$ l droplets containing approx. $10^{3}$ conidia. Upon inoculation, leaves were incubated at $4{ }^{\circ} \mathrm{C}$ in the dark. Radial growth was determined as increase in diameter after lesions had extended beyond inoculation spot over a 48-h timespan (72 to $96 \mathrm{~h}$ post inoculation $)$. $\mathrm{n}=$ total number of inoculation droplets per strain; $-=$ not done. $\mathrm{SD}=$ standard deviation. Statistical analysis was performed with a $t$ test. Conidia germination rate was always between 70 and $80 \%$. 
all other mutants. Only gene disruption of pecA, encoding the endoPG P2c from the saprophytic fungus Aspergillus flavus, resulted in a reduced aggressiveness, i.e., a decreased invasion of cotton bolls (Shieh et al. 1997). Interestingly, this gene is constitutively expressed, analogous to the Bcpg 1 gene of $B$. cinerea. Since the $B$ cpg 1 mutants also exhibit a reduced radial growth on PGA as sole carbon source, the absence of the BcPG1 isozyme apparently results in a reduced ability to degrade the complex pectin structures present in the cell wall. Therefore, the retarded invasion of the tissue surrounding the inoculation spot (Tables 1-3, Fig. 5) is most probably caused by a reduced maceration capability. In concordance with this, it has been reported that PG$\mathrm{A}$ is the only $B$. cinerea endoPG isozyme that is secreted in the outer regions of the lesions (Kamoen and van der Cruyssen, 1996). Several other endoPG isozymes, some of which are induced by the breakdown product of polygalacturonase action, galacturonic acid (van der Cruyssen et al. 1994), might serve in the further degradation of tissue that is already colonized. Therefore, it cannot be excluded that the reduced virulence displayed by the Bcpg 1 mutants is not solely the result of the absence of BcPG1 degrading activity, but could also be attributed to an altered induction of other polygalacturonases.

Our observation that a CWDE of $B$. cinerea is required for full virulence may be related to the fact that the fungus causes soft rot on many plant tissues. There is substantial evidence that CWDEs from bacterial plant pathogens causing soft rot are involved in pathogenesis. Elimination of several pectinases in Erwinia chrysanthemi independently influences maceration of potato tubers (reviewed by Barras et al. 1994). Similar results were obtained in studies on CWDEs of $\mathrm{Er}$ winia carotovora (Barras et al. 1994) and Ralstonia solanacearum (Schell et al. 1988).

Oligogalacturonides have been identified as elicitors of plant defense responses (de Lorenzo et al. 1990). A decrease in the release of oligogalacturonides, as a result of the elimination of BcPG1, might therefore reduce the plant response. An extensive study on the expression of other members of the endoPG gene family, presumably corresponding to the weakly hybridizing bands in Figure 1C, will be performed in several hosts as well as in liquid cultures and will provide more insight into the function of these enzymes in pathogenesis. Elimination of other endoPGs with different regulatory characteristics, and of other types of CWDEs in $B$. cinerea as well as in other soft rot-causing fungi such as the related $S$. sclerotiorum, will provide further insight into the role of CWDEs in fungal pathogenesis.

\section{MATERIALS AND METHODS}

\section{Growth of fungal strains and tomato plants.}

Fungal strains SAS56, (van der Vlugt-Bergmans 1993), B05.10 (haploid derivative of SAS56 (van Kan et al. 1997), and T 132 (B05.10 transformant containing a single copy of a hygromycin resistance gene cassette in the cutA locus) (van Kan et al. 1997) were maintained and conidia were isolated as described (Benito et al. 1998). Tomato plants (Moneymaker genotype $C f 4$ ) were grown for 4 to 6 weeks in 1-liter pots in potting soil in a climate chamber at $24^{\circ} \mathrm{C}$ with a 16-h photoperiod. Additional nutrients per pot were $1 \mathrm{ml}$ of FeNaEDTA (35 $\mathrm{g} \mathrm{l}^{-1}$ ) (Fluka, Buchs, Switzerland) at seed germination, $1 \mathrm{ml}$ of micronutrients $\left(2.86 \mathrm{~g} \mathrm{l}^{-1} \mathrm{H}_{3} \mathrm{BO}_{3}, 1.558\right.$ $\mathrm{g} \mathrm{l}^{-1} \mathrm{MnSO}_{4} \cdot \mathrm{H}_{2} \mathrm{O}, 0.08 \mathrm{~g} \mathrm{l}^{-1} \mathrm{CuSO}_{4} \cdot \mathrm{H}_{2} \mathrm{O}, 0.22 \mathrm{~g} \mathrm{l}^{-1}$ $\mathrm{ZnSO}_{4}, 0.0196 \mathrm{~g} \mathrm{l}^{-1}\left(\mathrm{NH}_{4}\right)_{6} \mathrm{Mo}_{7} \mathrm{O}_{24} \cdot{ }_{4} \mathrm{H}_{2} \mathrm{O}$; Merck, Darmstadt, Germany) at 3 days after seed germination and $5 \mathrm{ml}$ of Hoagland (5 mM Ca(NO $\left.)_{3}\right)_{2}, 5 \mathrm{mM} \mathrm{KNO}_{3}, 2 \mathrm{mM} \mathrm{MgSO}_{4}, 1$ $\mathrm{mM} \mathrm{KH} \mathrm{PO}_{4}$; Merck) on a weekly basis.

\section{Isolation of the Bcpg1 gene and Southern analysis.}

A genomic $\lambda$-EMBL3 library of $B$. cinerea SAS56 (Kusters-van Someren et al. 1992) was screened with the 0.7$\mathrm{kb}$ SalI fragment from the pgaII gene from A. niger (Bussink et al. 1990) as a probe. Positive phages were purified and characterized. Hybridizations were performed at $65^{\circ} \mathrm{C}$ in 50 $\mathrm{mM}$ Tris $\mathrm{pH} 7.5,10 \mathrm{mM}$ EDTA, $0.5 \%$ sodium dodecyl sulfate (SDS), 0.9 M NaCl, 0.09 M Na-citrate containing $1 \mathrm{~g} \mathrm{l}^{-1} \mathrm{Fi}^{-}$ coll (Type 400; Pharmacia, Uppsala, Sweden), $1 \mathrm{~g} \mathrm{l}^{-1}$ polyvinylpyrrolidone, $1 \mathrm{~g} \mathrm{l}^{-1}$ bovine serum albumin (Boehringer, Mannheim, Germany). Subsequent washings were performed at $65^{\circ} \mathrm{C}$ in $0.5 \times \mathrm{SSC}(1 \times \mathrm{SSC}$ is $0.15 \mathrm{M} \mathrm{NaCl}$ plus $0.015 \mathrm{M}$ sodium citrate), $0.1 \%$ SDS for high stringency conditions and in $2 \times \mathrm{SSC}, 0.1 \% \mathrm{SDS}$ for low stringency.

\section{Inoculation of tomato leaves.}

Harvest and pre-incubation of conidia, and tomato leaf handling, were performed as described (Benito et al. 1998). Virulence assays were performed by droplet inoculations of leaflets of compound leaves. The left part of each leaflet, except the apical, was inoculated with five $1-\mu l$ droplets, containing $10^{3}$ conidia, of a Bcpg 1 elimination transformant, whereas the right part was identically inoculated with the control (either recipient strain $\mathrm{B} 05.10$ or vector control $\mathrm{T} 132)$. Incubations were performed at 20 and $4^{\circ} \mathrm{C}$ as described (Benito et al. 1998). Lesion diameters were measured with a caliper. Viability of conidial suspensions was determined by plating dilutions of the pre-incubation suspensions on malt broth agar (MBA; Oxoid; Basingstoke, Hampshire, UK). Germination frequencies and radial outgrowth were measured. Foliar spray inoculations and incubations were performed as described (Benito et al. 1998).

\section{Fruit inoculations.}

Tomato fruits (cv. Carlita) were a gift from De Ruiter Seeds (Bergschenhoek, The Netherlands) or commercially obtained. Apple fruits (cv. Jonagold or cv. Braeburn) were commercially obtained. Conidia were harvested and pre-incubated as described (Benito et al. 1998). Fruits were surface disinfected with $70 \%$ ethanol and inoculated in small punctures with $5-\mu 1$ droplets containing $5 \times 10^{3}$ conidia. A BcPG1 mutant and a control strain were inoculated onto each fruit, at two positions each. Fruits were subsequently incubated in a $30 \times 45 \mathrm{~cm}$ plastic box on a plastic grid. Wet paper was placed beneath the grid in order to maintain a high humidity. Boxes were covered with a plastic, transparent lid. Apples were incubated at $20^{\circ} \mathrm{C}$ with a 16 -h photoperiod whereas the tomato fruits were incubated at $4^{\circ} \mathrm{C}$ in the dark. Lesion diameters were measured with a caliper.

\section{RNA analysis.}

RNA was extracted as described (van Kan et al. 1992), denatured by glyoxylation, and subsequently electrophoresed 
(Sambrook et al. 1989). Blotting and hybridizations (van der Vlugt-Bergmans et al. 1997) were performed with a radiolabeled PstI-Bam HI fragment of the Bcpg 1 coding sequence or a radiolabeled 320-bp PCR fragment from the BcactA gene (Benito et al. 1998). Fragments were radiolabeled with the Random Primers DNA Labeling System according to the manufacturer's description (Life Technologies, Gaithersburg, MD) and Redivue $\alpha^{32} \mathrm{P}$-dATP (Amersham, Buckinghamshire, UK). Autoradiographs were made by 48 -h exposure of Kodak$\mathrm{S}$ film at $-70^{\circ} \mathrm{C}$ with two intensifying screens.

\section{Construction of Bcpg1 replacement plasmid.}

All cloning steps were done by blunt-ended ligation of fragments, by standard methods. An SstI/HindIII cassette from pOHT, conferring resistance to hygromycin (Hilber et al. 1994), was ligated into p25\#BP, a $5^{\prime}$ BamHI/Pst I Bcpg 1 subclone comprising the $5^{\prime}$ flanking sequence as well as a part of the coding sequence, resulting in plasmid $\mathrm{p} \Delta 1$ (see Figure 4A, Step 1). A KpnI/SalI fragment from Bcpg1 subclone $\mathrm{p} 25 \# 9 \mathrm{H}$, comprising the $3^{\prime}$ terminal part of the Bcpg 1 gene as well as the $3^{\prime}$ flanking sequence, was cloned downstream of the resistance cassette in $\mathrm{p} \Delta 1$ (see Figure 4A, Step 2). In the resulting plasmid, $\mathrm{p} \Delta \mathrm{PG} 1$ (Fig. 4B), $700 \mathrm{bp}$ of coding sequence are replaced with the hygromycin resistance cassette from pOHT.

\section{Transformation of $B$. cinerea.}

A linear DNA fragment, excised from $\mathrm{p} \Delta \mathrm{PG} 1$ with Sst $\mathrm{I}$ (Fig. 4B), was used for transformation. Strain B05.10 was transformed as described (Hamada et al. 1994) with slight modifications. DNA $(1 \mu \mathrm{g})$ was added to $10^{7}$ protoplasts in 50 $\mu \mathrm{l}$ of $0.6 \mathrm{M} \mathrm{KCl}, 50 \mathrm{mM} \mathrm{CaCl} 2$, and $2.5 \mu \mathrm{l}$ of $50 \mathrm{mM}$ spermidine (Sigma, St. Louis, MO) was added prior to a 5-min incubation on ice; then $50 \mu \mathrm{l}$ of $25 \%$ (wt/vol) PEG (polyethylene glycol) 3350 (Sigma) in $10 \mathrm{mM}$ Tris pH 7.4, $50 \mathrm{mM}$ $\mathrm{CaCl}_{2}$ was added and the mixture was incubated at $20^{\circ} \mathrm{C}$ for $20 \mathrm{~min}$. An additional aliquot of $250 \mu \mathrm{l}$ of PEG was added followed by a 10 -min incubation at $20^{\circ} \mathrm{C}$; then, $750 \mu \mathrm{l}$ of 0.6 $\mathrm{M} \mathrm{KCl}, 50 \mathrm{mM} \mathrm{CaCl} 2$ was added prior to plating on agar plates containing $0.6 \mathrm{M}$ sucrose, $5 \mathrm{mM}$ HEPES (N-2hydroxyethylpiperazine- $\mathrm{N}^{\prime}$-2-ethanesulfonic acid) $\mathrm{pH} 6.5,1$ $\mathrm{mM}\left(\mathrm{NH}_{4}\right) \mathrm{H}_{2} \mathrm{PO}_{4}$ (Merck) and $25 \mu \mathrm{g}$ of hygromycin B per ml (Sigma). Emerging colonies were transferred to MBA plates containing $100 \mu \mathrm{g}$ of hygromycin B per ml.

Hyphal tips of hygromycin B resistant colonies were transferred to MBA containing $100 \mu \mathrm{g}$ of hygromycin B per $\mathrm{ml}$ prior to a transfer to potato dextrose agar (PDA; Merck) supplemented with $300 \mathrm{~g}$ of pulped tomato leaves per liter. Conidia were isolated and replated on MBA plates containing $100 \mu \mathrm{g}$ of hygromycin B per ml. Germlings from single conidia were isolated and transferred to tomato-leafsupplemented PDA. For Southern analysis, conidia were isolated as previously described (Benito et al. 1998), and subsequently incubated for $16 \mathrm{~h}$ at $20^{\circ} \mathrm{C}$ in a rotary shaker at 180 rpm (Gallenkamp Rotary Incubator; Gallenkamp, UK) in B5 medium including vitamins (Duchefa; Haarlem, The Netherlands), supplemented with $10 \mathrm{mM}$ sucrose and 10 $\mathrm{mM}\left(\mathrm{NH}_{4}\right) \mathrm{H}_{2} \mathrm{PO}_{4}$. Mycelium was harvested by filtration on Miracloth (Calbiochem, La Jolla, CA), dried on Whatman paper, and subsequently ground under liquid nitrogen. Genomic DNA was isolated as described (Möller et al.
1992), digested with restriction enzymes, and electrophoresed on $0.6 \%$ agarose gels. Genomic DNA was alkali blotted onto Hybond $\mathrm{N}^{+}$(Amersham) according to the manufacturer's description. Hybridizations and washings were performed as described (van der Vlugt-Bergmans et al. 1997). Autoradiographs were made by $24-\mathrm{h}$ exposure of Kodak-S films at $-70^{\circ} \mathrm{C}$ with two intensifying screens.

\section{ACKNOWLEDGMENTS}

We thank M. Ward from Genencor Inc. for providing the plasmid pOHT, B. van der Knaap from De Ruiter Seeds for providing tomato fruits, M. Kusters-van Someren for providing the genomic library, and P. Büttner and P. Tudzynski for providing strain B05.10. We also thank E. Hoffland for useful recommendations about tomato plant culturing and P. J. G. M. de Wit and J. P. Wubben for critically reading the manuscript. This research was supported by the Dutch Technology Foundation (STW), grant no. WBI 33.3046.

\section{LITERATURE CITED}

Annis, S. L., and Goodwin, P. H. 1997. Recent advances in the molecular genetics of plant cell wall-degrading enzymes produced by plant pathogenic fungi. Eur. J. Plant Pathol. 103:1-14.

Apel-Birkhold, P. C., and Walton, J. D. 1996. Cloning, disruption, and expression of two $\beta 1,4$,-xylanase genes, XYL2 and XYL3 from Cochliobolus carbonum. Appl. Environ. Microbiol. 2:4129-4135.

Barras, F., van Gijsegem, F., and Chatterjee, A. K. 1994. Extracellular enzymes and pathogenesis of soft rot Erwinia. Annu. Rev. Phytopathol. 32:201-234.

Benen, J., Parenicova, L., Kusters-van Someren, M., Kester, H., and Visser, J. 1996. Molecular genetic and biochemical aspects of pectin degradation in Aspergillus. Pages 331-348. in: Pectins and Pectinases. J. Visser and A. G. J. Voragen, eds. Elsevier Sciences, Amsterdam.

Benito, E. P., ten Have, A., van't Klooster, J. W., and van Kan, J. A. L. 1998. Fungal and plant gene expression during synchronized infection of tomato leaves by Botrytis cinerea. Eur. J. Plant Pathol. 104:207220.

Bowen, J. K., Templeton, M. D., Sharrock, K. R., Crowhurst, R. N., and Rikkerink, E. H. A. 1995. Gene inactivation in the plant pathogen Glomerella cingulata: Three strategies for the disruption of the pectin lyase gene pnlA. Mol. Gen. Genet. 246:196-205.

Bussink, H.-J., Kester, H. C., and Visser, J. 1990. Molecular cloning, nucleotide sequence and expression of the gene encoding prepropolygalacturonase II of Aspergillus niger. FEBS Lett. 273:127-130.

Clark, C. A., and Lorbeer, J. W. 1976. Comparative histopathology of Botrytis squamosa and B. cinerea on onion leaves. Phytopathology 66:1279-1289.

de Lorenzo, G., Ito, Y., D’Ovidio, R., Cervone, F., Albersheim, P., and Darvill, A. G. 1990. Host-pathogen interactions: XXXVII. Abilities of the polygalacturonase-inhibiting proteins from four cultivars of Phaseolus vulgaris to inhibit the endopolygalacturonases from three races of Colletotrichum lindemuthianum. Physiol. Mol. Plant Pathol. 36:421-435.

Elad, Y., and Evensen, K. 1995. Physiological aspects of resistance to Botrytis cinerea. Phytopathology 85:637-643.

Ficket, J. W. 1982. Recognition of protein coding regions in DNA sequences. Nucleic Acids Res. 10:5303-5318.

Gao, S. J., Choi, G. H., Shain, L., and Nuss, D. L. 1996. Cloning and targeted disruption of enpg 1 , encoding the major in vitro extracellular endopolygalacturonase of the chestnut blight fungus, Cryphonectria parasitica. Appl. Environ. Microbiol. 62:1984-1990.

Görlach, J. M., van der Knaap, E., and Walton, J. D. 1998. Cloning and targeted disruption of $M L G 1$, a gene encoding two of three extracellular mixed-linked glucanases of Cochliobolus carbonum. Appl. Environ. Microbiol. 64:385-391.

Hamada, W., Reignault, P., Bompeix, G., and Boccara, M. 1994. Transformation of Botrytis cinerea with the hygromycin B resistance gene, hph. Curr. Genet. 26:251-255.

Hilber, U. W., Bodmer, M., Smith, F. D., and Köller, W. 1994. Biolystic transformation of conidia of Botryotinia fuckeliana. Curr. Genet. 25: 
124-127.

Jarvis, W. 1977. Botryotinia and Botrytis species. Taxonomy and pathogenicity. Can. Dep. Agric. Monogr. 15, Harrow, Ontario, Canada.

Johnston, D. J., and Williamson, B. 1992a. Purification and characterization of four polygalacturonases from Botrytis cinerea. Mycol. Res. 96:343-349.

Johnston, D. J., and Williamson, B. 1992b. An immunological study of the induction of polygalacturonases in Botrytis cinerea. FEMS Microbiol. Lett. 97:19-24.

Kamoen, O., and van der Cruyssen, G. 1996. Two secretions from Botrytis cinerea important for pathogenesis. Meded. Fac. Landbouwwet. Rijksuniv. Gent 61:251-260.

Kusters-van Someren, M. A., Manders, B. J. G., and Visser, J. 1992 Pectin degradation by Botrytis cinerea: A molecular genetic approach. Pages 30-36 in: Recent Advances in Botrytis Research. K. Verhoeff, N. E. Malathrakis, and B. Williamson, eds. Pudoc Scientific Pub., Wageningen, The Netherlands.

Leone, G., and van den Heuvel, J. 1987. Regulation by carbohydrates of the sequential in vitro production of pectic enzymes by Botrytis cinerea. Can. J. Bot. 65:2133-2141.

Mansfield, J. W., and Richardson, A. 1981. The ultrastructure of interactions between Botrytis species and broad bean leaves. Physiol. Plant Pathol. 19:41-48.

Möller, E. M., Bahnweg, G., Sandermann, H., and Geiger, H. H. 1992. A simple and efficient protocol for isolation of high molecular weight DNA from filamentous fungi, fruit bodies, and infected plant tissues. Nucleic Acids Res. 20:6115-6116.

Nielsen, H., Engelbrecht, J., Brunak, S., and von Heijne, G. 1997. Identification of prokaryotic and eukaryotic signal peptides and prediction of their cleavage sites. Protein Eng. 10:1-6.

Perpetua, N. S., Kubo, Y., Yasuda, N., Takano, Y., and Furusawa, I. 1996. Cloning and characterization of a melanin biosynthetic thrl reductase gene essential for appressorial penetration of Colletotrichum lagenarium. Mol. Plant-Microbe Interact. 9:323-329.

Rijkenberg, F. H. J., de Leeuw, G. T. N., and Verhoeff, K. 1980. Light and microscopy studies on the infection of tomato fruits by Botrytis cinerea. Can. J. Bot. 58:1394-1404.

Salinas, J. 1992. Function of cutinolytic enzymes in the infection of gerbera flowers by Botrytis cinerea. Ph.D. thesis. University of Utrecht, Utrecht, The Netherlands.

Sambrook, J., Fritsch, E. F., and Maniatis, T. A. 1989. Molecular Cloning: A Laboratory Manual. 2nd ed. Cold Spring Harbor Press, Cold Spring Harbor, NY.

Schaeffer, H. J., Leykam, J., and Walton, J. D. 1994. Cloning and targeted gene disruption of EXG1, encoding exo-beta1, 3-glucanase, in the phytopathogenic fungus Cochliobolus carbonum. Appl. Environ. Microbiol. 60:594-598.

Schell, M. A., Roberts, D. P., and Denny, T. P. 1988. Analysis of the
Pseudomonas solanacearum polygalacturonase encoded by $p g l \mathrm{~A}$ and its involvement in phytopathogenicity. J. Bacteriol. 170:4501-4508.

Scott-Craig, J. S., Cheng, Y.-Q., Cervone, F., de Lorenzo, G., Pitkin, J. W., and Walton, J. W. 1998. Targeted mutants of Cochliobolus carbonum lacking the two major extracellular polygalacturonases. Appl. Environ. Microbiol. 64:1497-1503.

Scott-Craig, J. S., Panaccione, D. G., Cervone, F., and Walton, J. D 1990. Endopolygalacturonase is not required for pathogenicity of Cochliobolus carbonum on maize. Plant Cell 2:1991-1200.

Shi, Z., and Leung, H. 1995. Genetic analysis of sporulation in Magnaporthe grisea by chemical and insertional mutagenesis. Mol. PlantMicrobe Interact. 8:949-959.

Shieh, M., Brown, R. L., Whitehead, M. P., Carey, J. W., Cotty, P. J., Cleveland, T. E., and Dean, R. A. 1997. Molecular genetic evidence for the involvement of a specific polygalacturonase, P2c, in the invasion and spread of Aspergillus flavus in cotton bolls. Appl. Environ. Microbiol. 63:3548-3552.

Sposato, P., Ahn, J. H., and Walton, J. D. 1995. Characterization and disruption of a gene in the maize pathogen Cochliobolus carbonum encoding a cellulase lacking a cellulose binding domain and hinge region. Mol. Plant-Microbe Interact. 8:602-609.

van der Cruyssen, G., de Meester, E., and Kamoen, O. 1994. Expression of polygalacturonases of Botrytis cinerea in vitro and in vivo. Meded. Fac. Landbouwwet. Rijksuniv. Gent 59:895-905.

van der Vlugt-Bergmans, C. J. B., Brandwagt, B. F., van't Klooster, J. W., Wagemakers, C. A. M., and van Kan, J. A. L. 1993. Genetic variation and segregation of DNA polymorphisms in Botrytis cinerea. Mycol. Res. 97:1193-1200.

van der Vlugt-Bergmans, C. J. B., Wagemakers, C. A. M., and van Kan, J. A. L. 1997. Cloning and expression of the cutinase A gene of Botrytis cinerea. Mol. Plant-Microbe Interact. 10:21-29.

van Kan, J. A. L., Joosten, M. H. A. J., Wagemakers, C. A. M., van den Berg-Velthuis, G. C. M., and de Wit, P. J. G. M. 1992. Differential accumulation of mRNAs encoding extracellular and intracellular PR proteins in tomato induced by virulent and avirulent races of $\mathrm{Cla}$ dosporium fulvum. Plant Mol. Biol. 20:513-527.

van Kan, J. A. L., van't Klooster, J. W., Wagemakers, C. A. M., Dees, D. C. T., and van der Vlugt-Bergmans, C. J. B. 1997. Cutinase A of Botrytis cinerea is expressed, but not essential, during penetration of gerbera and tomato. Mol. Plant-Microbe Interact. 10:30-38

Visser, J., Bussink, H.-J., and Witteveen, C. 1995. Gene expression in filamentous fungi: Expression of pectinases and glucose oxidase in Aspergillus niger. Pages 241-308 in: Gene Expression in Recombinant Microorganisms. A. Smith, ed. Marcel Dekker, New York.

Wasmann, C. C., and VanEtten, H. D. 1996. Transformation-mediated chromosome loss and disruption of a gene for pisatin demethylase decrease the virulence of Nectria haematococca on pea. Mol. PlantMicrobe Interact. 9:793-803. 